\title{
The Government's Role in Improving the Creative Economy in Coastal Communities in Percut Village, Percut Sei Tuan District
}

\author{
Irwan Nasution*, Yurial Arif Lubis \\ Lecturer at Faculty of Politics and Social Science, University of Medan Area, Indonesia
}

*Corresponding Author: Irwan Nasution, Lecturer at Faculty of Politics and Social Science, University

of Medan Area, Indonesia

\begin{abstract}
In line with population growth and increased socio-economic development activities, coastal areas continue to grow. The consequence of this pressure on the coast is a management problem that arises because of conflicts of use by various stakeholders in the coastal area. Percut Village is a coastal area. It is a coastal village with a height of sea level ranging from 10-20 $\mathrm{m}$ with an average rainfall of $243 \%$. Initial observations of the income of this fishing group averaged around Rp. 724,032.41/ once at sea. Besides the low income, Percut fishermen have a low level of education. This condition causes obstacles to the development of this region. The task of government is to serve and regulate society. Where the service task is to emphasize efforts to prioritize the public interest, facilitate public affairs and provide satisfaction to the public. One of them is in increasing public opinion through the creative economy. Therefore this research was conducted to study the role of government to improve location-specific people's economy in Percut village. From the results of this study, it was found that the Government had not played an optimal role in improving the creative economy in Percut Village. That role is as a catalyst, facilitator, and advocate, as a regulator, as consumers, investors, and entrepreneurs. The government has also not been proactive in assisting creative economic actors in managing patents, so that it can strengthen the image \& identity of Percut village. The role of the Government as a catalyst, facilitator and advocacy, although it is considered that the creative economy entrepreneurs are not doing well.
\end{abstract}

Keywords: The role of government; improvement of the creative economy, coastal communities

\section{INTRODUCTION}

The creative economy in Indonesia contributes significantly to the national economy. Based on the calculation of the Central Statistics Agency, during the 2010-2013 creative economy averaged 7.8\% of Indonesia's GDP. While the added value of the creative economy reached Rp 641.8 trillion with a growth of around $5.76 \%$, and the number of creative industries was recorded as many as 5.4 million businesses that absorbed the workforce. [1] The competitiveness of Indonesia's creative industries is identified based on seven main dimensions: creative resources, supporting resources, industry, financing, marketing, infrastructure and technology, and institutions. When mapped based on the seven dimensions, the average competitiveness of 15 creative industry sub-sectors is still relatively low.

This is caused by the financing that is considered difficult to be fulfilled by the creative industry sector actors, especially those who are still beginners so that the difficulty of financing makes the Indonesian creative industry considered less competitive. This problem is found in various parts of Indonesia, especially in the coastal areas with limited access to information. In addition, the limited banking credit facilities, procedures and requirements for bank credit that are too complex and bureaucratic, the inability to provide additional collateral, high credit interest, and the limited reach of bank credit in the regions cause problems in financing creative industries. Therefore, we need an effort to empower people in a sustainable manner.

Empowerment will make empowered people who know, understand, understand, be motivated, have opportunities, take advantage of opportunities, have energy, be able to work together, know various alternatives, be able to make decisions, dare to take risks, able to find and capture information and be able to act according to the situation. This empowerment process will give birth to people who have the expected nature, so that the sustainability of the social system and economic growth of the coastal 
The Government's Role in Improving the Creative Economy in Coastal Communities in Percut Village, Percut Sei Tuan District

area can be improved. One of the main economic empowerment of the people is through creative industries.

In general, a strong reason why this creative industry needs to be improved, because this creative industry sector has a significant economic contribution to the economy of the community, especially coastal communities, can create a positive business climate, can strengthen the image \& identity of the region, support the utilization of renewable resources, is central to creating innovation and shaping creativity, and has a positive social impact. Creative industry is like a building that will strengthen the economy, with the foundation, pillars and roofs as building elements. The creative industry is inseparable from the relationship between intellectuals, business and government, which is called the "triple helix" system which is the main actor driving the birth of creativity, ideas, science and technology which is vital for the growth of the creative industry..

A close relationship, mutual support and mutual symbiosis between the three actors in relation to the foundation and pillars of the creative industry model will produce a creative industry that stands firm and sustainable. The government in question is the regional government government associated with the improvement of the creative economy, both the linkages in substance and administration. The effort must also be synergized with the university as a scientist with research competence through the Research and Service Institute. The community, has prepared young people to be fostered, in the form of cooperation with regional apparatus organizations (OPD) at the district / city level. It also empowers and provides guidance to entrepreneurs so that existing businesses can experience significant progress, thus accelerating their economic well-being.

So far, the Deli Serdang Regency Government, especially in Percut Sei Tuan Subdistrict, has been focusing on working on the creative economy, which is recognized as having the potential to create employment opportunities that can contribute to local income. According to the Head of Balitbang Deli Serdang, the creative economy is considered to be one of the efforts to overcome the problem of poverty in the coastal areas of Percut Sei Tuan district. The potential of marine wealth and strong cultivation forms the foundation for the growth of creative industries in the region. And the diversity of natural resources as raw materials for creative industries, will be able to bring up a variety of crafts.

The results of the study Harjawati showed that the implementation of the creative economy in the South Tangerang City area was already running but was still not optimal. This is proven from 164 MSME Culinary Industries, only 12 MSMEs that can be considered superior and need attention to be developed. The role of the government in supporting the pattern of development of financial institutions in the centers of the creative economy-based industries in the South Tangerang City area is limited as a facilitator, which is assisting licensing and increasing the increase of Land Rights (Certificates) for creative industries. The role of the government in providing priority aid and financing facilities in the creative economy industry has fulfilled the requirements, in the sense of only providing letters of recommendation for the creative industries.

Based on the reasons above, then the creative economy should be an industrial sector that is interesting to be developed and studied in a study. In an organizational review, the role is a component of the organizational system which is work behavior that can produce several changes. So it can be concluded that the role is an action that contributes to produce some changes. This definition is very relevant to local governments that have a role in improving the function of traditional markets in encouraging the development of community economic activities. In this case, the government in question is the Regional Government of Deli Serdang Regency especially Percut Sei Tuan District as the organizer of government affairs by the Regional Government. The intended government is the regional government that is related to the development of the creative economy, both related to the substance and administration. The central government includes departments and agencies. Local government includes regional government level I, II, to the lowest hierarchy of local government. [2] Government involvement is at least motivated by several things, among others:

- Market failure

- Mobilization and allocation of resources

- Psychological impact and impact on attitude / behavior

- Equitable development. 
The Government's Role in Improving the Creative Economy in Coastal Communities in Percut Village, Percut Sei Tuan District

Until now, several initiatives that have been carried out by the government to develop this creative industry include:

- Law Number 5 of 1984 concerning Industry, namely in Chapter VI Article 17 which states that industrial product design is legally protected.

- Law Number 31 of 2000 concerning Industrial Designs in

- Protection of Intellectual Property Rights.

- Decree of the Minister of Industry and Trade Number

- 20 / MPP / Kep / I / 2001 concerning the establishment of the National Design Council / National Design Center (PDN).

- National Design Center (PDN) Since 2001 to 2006, has chosen 532 best Indonesian product designs.

- In 2006, the Ministry of Trade of the Republic of Indonesia initiated the launch of the Indonesia Design Power program consisting of the Indonesian Ministry of Trade, the Indonesian Ministry of Industry, the Ministry of Cooperatives and SMEs and the Indonesian Chamber of Commerce (KADIN) [3].

In 2007, the Indonesian Cultural Week Exhibition was held, based on the direction of the President, and was initiated by the Office of the Coordinating Minister for Public Welfare, and involved crossdepartments including: the Ministry of Industry, Trade, Culture \& Tourism, and the Ministry of SMEs \& Cooperatives. In 2007, the Indonesian Ministry of Trade launched the results of a mapping study of the Indonesian Creative Industry and established 14 Indonesian Creative Industry subsectors based on an academic study of the Indonesian Industrial Business Standard Classification (KBLI) compiled from the Central Statistics Agency data and other data sources (associations, creative communities, institutions education, research institutions) that are released in print media, related to the creative industries.

The main role of the Government in improving the creative economy is:

a. Catalysts, facilitators, and advocacy. That is the role of the Government in providing stimuli, challenges, encouragement, so that business ideas move to a higher level of competence. Not always that support must be in the form of financial assistance, incentives or protection, but it can also in the form of government commitment to use political power proportionally and by providing public administration services properly

b. Regulator. Namely the role of the Government in producing policies related to people, industry, institutions, intermediation, resources, and technology. The government can strengthen the development of creative industries if the government is able to make policies that create a conducive business climate for creative industries. The government must also regulate that the policies that have been issued are carried out properly.

c. Consumers, investors and even entrepreneurs. The government as an investor must be able to empower state assets to be productive in the scope of the creative industries and be responsible for investment in industrial infrastructure. As a consumer, the government needs to revitalize its procurement policies with priority in the use of creative products. As an entrepreneur, the government indirectly has authority over state-owned enterprises (BUMN).

To that end, local governments are expected to have the ability to identify and manage the potentials that exist in their regions, to be used effectively and efficiently in order to carry out development activities in order to improve the quality of life of the people and their regions. Thus the local government is obliged to consistently manage the potentials that can be developed, one of which is the development and management in coastal areas, which are expected to increase regional income and improve welfare society, nation and State. [4]

The failure and success of development and community empowerment is determined by the ability of all parties involved in the process of community development to understand the reality of the community and the environment of belief systems and community value systems about the meaning of change and the meaning of the future, and the mindscape of the community will determine the success of a development program or project and empowering the community. In order for the 
The Government's Role in Improving the Creative Economy in Coastal Communities in Percut Village, Percut Sei Tuan District

community to be truly involved in every process of change, the communication patterns used must be living and rooted in the community.

Fishing communities who have awareness and have a high ability of science and technology will be better able to survive. Changes in mindset by relying only on one source of income, becoming more than one source makes the fishing community advanced. Although community empowerment efforts are not easy to achieve optimal results, the atmosphere of regional autonomy and political openness will provide hope for community empowerment, especially for people in the coastal areas as subjects. Creative economy is a concept for realizing sustainable economic development based on creativity. Utilization of resources that are not only renewable, even unlimited, namely ideas, ideas, talents and creativity. The creative mindset that is needed to continue to grow and survive and survive in the future[5].

So it can be concluded that to be a creative worker is not enough to have talent in drawing, dancing, singing and writing stories. He must have the ability to organize multi-disciplinary ideas and also the ability solve problems in ways that are out of habit.

\section{Materials \&MethodS}

\subsection{Research Design}

This research was carried out by Percut Village, Percut Sei Tuan District, Deli Serdang Regency. This location is a place of research because this area is a coastal area where the majority of the population earns a living as a fisherman. This type of research is using descriptive qualitative research methods with a case study approach. The informants in this study were divided into 3 parts, namely the main informant, key informants and additional informants. The main informant which consists of 20 informants. Key informants are the fishermen's wife and the fisherman's child. Additional informants are toke shells and hamlet heads and entrepreneurs. Data collection techniques were carried out by participatory observation and in-depth interviews and using a questionnaire through the Focus Group Discussion (FGD) activities.

\subsection{Data Analyzis Technique}

Measurement technique The measurement used in this study is interval measurement. According to Singarimbun \& Effendi said interval size is the ordering of people or objects based on attributes other than that this size also provides information about the interval between one or an object with another person or object. The scale used is 5 Likert scale with alternative answers $1=$ strongly disagree, $2=$ disagree, $3=$ neutral, $4=$ agree and $5=$ strongly agree. Next, the total score of each Government role is used to find out how well the Government agrees / plays the respective roles according to respondents' responses [6]. There are two methods of data analysis that will be carried out by researchers in conducting this research, namely descriptive and qualitative methods. The descriptive analysis technique used is to use a percentage formula, namely: Percentage $=\sum \mathrm{x} 100 \%$

The percentage intervals used according to Likert are as follows. [7]

Table1: Kategori Nilai

\begin{tabular}{|c|c|c|}
\hline No. & Rentang Nilai & Criteria \\
\hline 1 & $85 \%-100 \%$ & Very Good \\
\hline 2 & $75 \%-84 \%$ & Good \\
\hline 3 & $60 \%-74 \%$ & Enough \\
\hline 4 & $40 \%-59 \%$ & Not Good \\
\hline 5 & $39 \%-0 \%$ & Very Poor \\
\hline
\end{tabular}

\section{RESULTS \& DISCUSSION}

\subsection{Results}

\subsubsection{The Government's Role in Improving the Creative Economy in Percut Village as Catalyst}

The role of the government in Percut village in enhancing the creative economy aims to realize sustainable economic development based on creativity. Utilization of resources that are not only renewable, even unlimited, namely ideas, ideas, talents and creativity. The economic value of a product or service in the creative era is no longer determined by the raw materials or production 
The Government's Role in Improving the Creative Economy in Coastal Communities in Percut Village, Percut Sei Tuan District

systems as in the industrial era, but rather the use of creativity and innovation creation through increasingly advanced technological developments. The industry can no longer compete in the global market by only relying on it price or product quality only, but must compete based on innovation, creativity and imagination.

Creative Economy in which there are creative industries have a high bargaining power in a sustainable economy because individuals have creative capital that they use to create innovations. So it can be concluded that to be a creative worker is not enough to have talent in drawing, dancing, singing and writing stories. He must have the ability to organize multi-disciplinary ideas and also the ability to solve problems in ways that are out of the ordinary. The mission of the creative economy in Percut village is to optimize the development and preservation of local resources that are competitive, dynamic, and sustainable. Then develop creative industries that are competitive, growing, diverse, and quality and develop a conducive environment that mainstreams creativity in national development by involving all stakeholders. However, it is not easy to explore the potential and foster the creativity of the village community of Percut to be able to utilize domestic wastes and waste of marine products such as shells so that they can be of economic value. For this reason, the role of the government in implementing various empowerment programs based on the creative economy has not been optimal. For more details can be seen in the following table:

Table2: Public Opinion on the Government Carrying Out Assistance and Training for Entrepreneurs and the Community

\begin{tabular}{|l|l|l|l|}
\hline \multicolumn{1}{|c|}{ No. } & \multicolumn{1}{c|}{ Answer } & \multicolumn{1}{c|}{ Frequency } & Percentage \\
\hline 1. & Strongly Agree & 1 & $5 \%$ \\
\hline 2. & Agree & 1 & $5 \%$ \\
\hline 3. & Neutral & 5 & $25 \%$ \\
\hline 4. & Not Agree & 13 & $65 \%$ \\
\hline 5. & Strongly Disagree & 0 & $0 \%$ \\
\hline & Total & 20 & $100 \%$ \\
\hline
\end{tabular}

Source: Fields Data, 2019

Based on the data table above shows that the people who answered agreed and strongly agreed to the role of the government to provide assistance and training by $5 \%$ and the people who answered strongly agreed by $5 \%$, the people who answered neutral by $25 \%$ and answered disagreed by $65 \%$. It can be concluded that the people who answered agreed with the government's efforts to provide assistance and training were lower in percentage with the number of people who answered disagreed at $65 \%$. This means that so far the fishing communities and creative economy entrepreneurs have never attended intensive training and assistance. That is due to low willingness, limited information and limited facilitators and apathy towards environmental conditions. Basically the community wants the presence of the government to assist the community and entrepreneurs in order to improve their creative economy. Ole therefore needs to be done intensively training and mentoring creative economy in Percut Village according to community expectations.

From the explanation of the informant above, it is also illustrated in the following table 4 that describes the responses of respondents regarding the Government's role as facilitator. This analysis aims to determine the role of government in improving the creative economy in the village of Percut. To find out more details can be seen in table 3 .

Table3: Participation in Training and Business Assistance

\begin{tabular}{|l|l|l|}
\hline \multicolumn{1}{|c|}{ Answer } & \multicolumn{1}{|c|}{ Frequency } & \multicolumn{1}{c|}{ Percentage } \\
\hline Ever & 7 & $35 \%$ \\
\hline Never & 13 & $65 \%$ \\
\hline Total & 20 & $100 \%$ \\
\hline
\end{tabular}

Based on the data in table 9 above, it shows that there were 7 (35\%) respondents who had attended training, while $13(65 \%)$ had never participated in training. The results of this study indicate that the number of respondents who have an interest in participating in training is greater than those who do not participate. This is due to time constraints and also prioritizes the main jobs that are more quickly profitable such as trading and fishing. 
The Government's Role in Improving the Creative Economy in Coastal Communities in Percut Village, Percut Sei Tuan District

Based on the explanation from the informants above, it can be seen that all Percut people have a willingness to be creative but are limited by their ability to access capital. As an area that also has potential in the creative economy field, Percut Sei Tuan sub-district government encourages the growth and development of creative industries in all districts to boost the economy of its people and it tries to continue to foster community to become entrepreneurs in the field of creative industries. Although the creative industry has enormous potential especially those based on local wisdom, in reality the creative industry in the village of Percut still has some obstacles and has not developed rapidly.

Government support for the empowerment and improvement of small and medium industries to take part in the creative industries has not yet materialized. This means that the opportunity for Small Industries to become creative industry players is not yet wide open. But of course this can not necessarily be done. Business actors and craftsmen need to get a stimulus in the form of a transfer of knowledge and research results that contain technological advances, innovation and creativity. In this case, it is clear how important the government's contribution is to contribute to the improvement of the creative economy in Percut village. The government has a role in the ease of licensing and preparing physical facilities and infrastructure for creative industries such as market locations, exhibition activities, online information and marketing facilities.

The statement from the informant above shows that marketing facilities are needed for creative craftsmen to promote their products. In order to make it easier for visitors to buy creative products from the Percut community. But in reality so far the marketing methods are still carried out by each of the artisans by peddling and traveling around the village.

\subsubsection{The Government's Role in Improving the Creative Economy in Percut Village as Regulator}

A regulation is a set of rules intended to provide protection and benefits for the community at large or to a group of people. The benefits of the regulation can be seen from two sides, namely from the side of the government as the regulator and from the side of the entrepreneur as the object of licensing. For Percut village government, licensing is needed to maintain public order and provide protection to the community at large. For entrepreneurs, licensing should provide social and economic benefits. If a policy or regulation is not in line with expectations, of course the policy must be evaluated because with the evaluation will get relevant input with policy mismatches with expected performance.

Likewise in running a creative economy business in Percut Village, government policies always support the potential of people who wish to develop their expertise in processing raw materials from marine products. But this support has not been optimally accompanied by training in human resources in creating a creative economy. The policies formulated by the Government are implemented in accordance with the rules and are considered to be very good implementation. That is, policies relating to the creative industries in the village of Percut are actually implemented according to the rules set with reference to local government regulations. The important thing that has been deemed to be inadequate by the creative economy entrepreneurs is that the regional government is not optimally providing socialization and facilitating bureaucracy regarding licensing and ownership (Intellectual Property Rights. Creative economy entrepreneurs in Percut village consider that the government's real role in determining administrative \& technical requirements in assistance is not yet seen capital and regional taxation that are "not friendly" to the development of the creative industries, the opinions of these respondents can be seen in the following table:

Table4: Respondents' Answers about Tax Imposition

\begin{tabular}{|l|l|l|l|}
\hline \multicolumn{1}{|c|}{ No. } & \multicolumn{1}{|c|}{ Answer } & \multicolumn{1}{c|}{ Frequency } & \multicolumn{1}{c|}{ Percentage } \\
\hline 1. & Strongly Agree & 1 & $5 \%$ \\
\hline 2. & Agree & 1 & $5 \%$ \\
\hline 3. & Neutral & 1 & $5 \%$ \\
\hline 4. & Not Agree & 17 & $85 \%$ \\
\hline 5. & Strongly not Agree & 0 & $0 \%$ \\
\hline & Total & 20 & $100 \%$ \\
\hline
\end{tabular}

Based on the data above shows that the community those who answered strongly agreed about the government's policy of imposing taxes on creative economy entrepreneurs by 1 person (1 while those who answered disagreeing were 17 people $(85 \%)$. This means that more people disagree if the government makes a policy of taxing creative economy entrepreneurs. With the reason can hamper 
The Government's Role in Improving the Creative Economy in Coastal Communities in Percut Village, Percut Sei Tuan District

the development of creative businesses, the problem if taxed can reduce the income of entrepreneurs, although in principle the tax is used for development such as infrastructure and social assistance.

Table5: Follow the Government Policy

\begin{tabular}{|l|l|l|l|}
\hline \multicolumn{1}{|c|}{ No. } & \multicolumn{1}{|c|}{ Answer } & \multicolumn{1}{c|}{ Frequency } & \multicolumn{1}{c|}{ Percentage } \\
\hline 1. & Strongly Agree & 10 & $50 \%$ \\
\hline 2. & Agree & 4 & $20 \%$ \\
\hline 3. & Neutral & 0 & 0 \\
\hline 4. & Not Agree & 6 & $30 \%$ \\
\hline 5. & Strongly not Agree & 0 & 0 \\
\hline & Total & 20 & $100 \%$ \\
\hline
\end{tabular}

Based on the data above shows that the public answered strongly agree (50\%) by following government policy rules, while those who did not agree by following government policy rules were 4 people (20\%). If compared to the people who agree with the policy, there are more government regulations than those who disapprove. That is because the community considers that the existence of government regulations can slow down creative efforts, especially in obtaining permits and administration. This means that in order to improve the creative economy in Percut Village, the role of the government is needed to facilitate licensing and administrative arrangements for creative entrepreneurs.

Explanation of the informant above explains that the need for policies on supporting employers and craftsmen in the form of licensing is very much needed by the community. But so far, what the public expects is a form of commitment from the government in providing capital. Most artisans still use their own capital because of the limited nominal lending from joint venture cooperatives. So, the role of government really does not look good in improving the creative economy.

\subsection{Discussion}

The creative economy can make a positive contribution to economic development both regionally and nationally. In an effort to improve it, there are still many problems found such as capital, human resources, copyright, and marketing factors that have caused the development of the creative industry sector in several regions in Indonesia to run optimally. Similar problem conditions are also experienced in the development of the creative economy in Percut Village. Efforts to increase the role of the creative economy sector in the economy in Percut Sei Tuan sub-district through the support of regional policies, facilitators and advocation as well as investment have not gone well. The contribution of the export value of the creative economy sector in Percut Village has not yet relied solely on conventional industries or home industries. To continue to develop the creative economy sector requires a regulation that contains a grand design of creative economic development that can accommodate various interests; the weakness factor of human resources of creative economy actors in innovating, can be overcome by the presence of universities or R\&D institutions in the region to produce technology packages or innovative ideas in increasing the added value of goods and services so that they are in accordance with market desires.

In line with his opinion Creative economy as an economic activity where the input and output are ideas. Or in one short sentence, the essence of creativity is an idea. So you can imagine that only with the capital of ideas, a creative person can earn a relatively high income. To be a creative worker is not enough to have talent in drawing, dancing, singing and writing stories. He must have the ability to organize multi-disciplinary ideas and also the ability to solve problems in ways that are out of the ordinary. In addition, culture can influence the drive to plunge into creative economic endeavors. Culture is a way of life that is developed and shared by a group of people and is passed down from generation to generation. Culture is complex, abstract, and broad. Is complex because culture is an interrelated relationship that makes a culture that will always grow from generation to the next generation. Are abstract because culture cannot be seen in plain view. Culture can only be felt by us and it is only the result of culture that we can feel. Are broad because culture can affect the circumstances in accordance with the norms of customs that emerge in an area. Creative culture that grows in an area can support creative activities that will affect the value of an area. Creative culture in Percut Village is needed to support the creativity possessed by the entire community. Percut Village is known as a coastal village where many sea products and creative works show differences from other 
The Government's Role in Improving the Creative Economy in Coastal Communities in Percut Village, Percut Sei Tuan District

regions. Creative culture can grow inseparably from the participation of the existing community. Creative communities, urban infrastructure and business people themselves.

\section{CONClusion}

Based on the results of the analytical research and the findings of this study it can be concluded that the government has not optimally played its role in improving the creative economy in Percut Village. That role is as a catalyst, facilitator, and advocate, as a regulator, as consumers, investors, and entrepreneurs. The government has also not been proactive in assisting creative economic actors in managing patents, so that it can strengthen the image \& identity of Percut village. The role of the Government as a catalyst, facilitator and advocacy, although it is considered that the creative economy entrepreneurs are not doing well. So it is very important to conduct seminars, workshops and training in the fields of entrepreneurship, management and leadership, this activity is expected to be able to carry out the Government periodically so that it becomes a motivation for creative economy entrepreneurs in looking at the progress of their businesses that contribute a lot to the economy of Percut village.

\section{REFERENCES}

[1] Darmawan, H,. 2013. “Kamus Ilmiah Populer Lengkap. Yogyakarta : Bintang Cemerlang

[2] Harjawati, T., 2018. "Peran Pemerintah Dalam Pengembangan Lembaga Pembiayaan Di Sentra Industri Berbasis Ekonomi Kreatif (Studi Kasus Industri Kuliner Kota Tangerang Selatan”, Jurnal Sosio Didaktika: Social Science Education Journal, 5(1)

[3] https://percutseituan.wordpress.com/2016). Kusnadi.2002. Keberdayaan nelayan dan dinamika ekonomi pesisir. Jogyakarta.

[4] Ndakularak, E. 2014, dkk. Analisis Faktor-Faktor Yang Mempengaruhi Kesejahteraan Masyarakat Kabupaten/Kota Di Provinsi Bali, Artikel, Fakultas Ekonomi Universitas Udayana

[5] Pangestu, ME. 2008. "Pengembangan Industri Kreatif Menuju Visi Ekonomi Kreatif Indonesia 2025". Departemen Perdagangan Republik Indonesia

[6] Purnomo, A, Rochmat \& Cahya Ambarwati, Puput.,2016, "Analisis Statistic Ekonomi Dan Bisnis Dengan SPSS": Bandung: Bina Tama

[7] Sugiyono. 2007. Metode Penelitian Kuantitatif Kualitatif dan R\&D. Bandung: Alfabeta.

\section{AUTHORS' BIOGRAPHY}

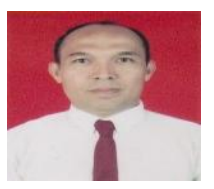

Irwan Nasution, M.AP is Lecturer at Faculty of Politics and Social Science, Majority of Public Administration, University Of Medan Area, Indonesia.

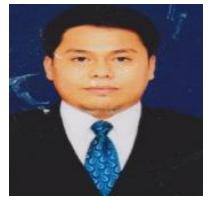

Yurial Arif Lubis, M.IP, is Lecturer at Faculty of Politics and Social Science, Majority of Public Administration, University Of Medan Area, Indonesia.

Citation: Irwan Nasution, Yurial Arif Lubis. "The Government's Role in Improving the Creative Economy in Coastal Communities in Percut Village, Percut Sei Tuan District". International Journal of Humanities Social Sciences and Education (IJHSSE), vol. 6, no.10, 2019, pp. 96-103. doi: http://dx.doi.org/10.20431/2349-0381. 0610011 .

Copyright: (C) 2019 Authors. This is an open-access article distributed under the terms of the Creative Commons Attribution License, which permits unrestricted use, distribution, and reproduction in any medium, provided the original author and source are credited. 